\title{
Ecological Genetics of Natural Strawberry Species
}

\author{
J.F. Hancock \\ Department of Horticulture, Michigan State University, East Lansing, MI 48824
}

\begin{abstract}
At least 15 species are currently recognized in the strawberry genus Fragaria, and one is worthy of recognition (Table 1). The cultivated strawberry $F$. ×ananassa is grown all over the arable world, but its progenitors $F$. chiloensis and $F$. virginiana are native only to the New World. F. virginiana is located in Canada and United States, while F. chiloensis is found in Chile and along the coast from California to the Aleutian Islands. Natural populations of $F$. ×ananassa are restricted to coastal California, Oregon, and Washington (Staudt, 1962). The most broadly distributed natural species is the diploid $F$. vesca, which inhabits North and South America, Europe, Asia, and Hawaii.

Strawberry species are found in a diverse array of climates, including temperate, grassland, mediterranean, and subtropical. The typical microenvironment of strawberries consists of moderate temperatures, high nutrient levels, high to moderate light levels, moderate moisture, and low salinity; but numerous exceptions exist. $F$. iinumae, $F$. vesca, and $F$. nipponica are located on very cold alpine mountains. F. moschata is found under heavy shade. $F$. chiloensis survives on nutrient-poor dunes with high salt levels. $F$. viridis tolerates high soil $\mathrm{pH}$ levels. $F$. orientalis, $F$. vesca, and $F$. virginiana have high resistance to heat and drought (Darrow, 1966; Goncharova, 1978; Goncharova and Dobrenkova, 1981; Hancock and Bringhurst, 1979a).

The various species also appear to have distinct photosynthetic patterns, although extensive surveys are just emerging. $F$. chiloensis has much higher maximum photosynthetic rates than $F$. vesca, $F$. virginiana, or $F$. Xananassa (Cameron and Hartley, 1988; Hancock et al., 1989; Chabot, 1978; Jurik et al., 1979). J. Flore, J. Caldwell, and J. Hancock (unpublished data) have preliminary information that indicates that $F$. virginiana plants may have higher photosynthetic temperature optima than $F$. chiloensis, and it may have higher shade tolerance.
\end{abstract}

As evidenced by their broad geographical and climatic ranges, substantial ecological differentiation has occurred not only between strawberry species, but also within them. Populations of $F$. vesca and $F$. chiloensis are found in various communities with very distinct ecological parameters (Table 2). Plants in each of the community types have unique multivariate morphologies (Jensen and Hancock, 1982) and physiological tolerances (Hancock and Bringhurst, 1978, 1979a). Angevine (1983), Holler and Abrahamson (1977), and Stadler et al. (1988) have also observed substantial ecological variation in $F$. virginiana for soil type, $\mathrm{pH}$, soil moisture content, and light levels.

Besides their proclivity for adaptation, strawberries are of great interest to ecologists working on theories of sexual evolution (Williams, 1975). Strawberries are ideal as they vary greatly in their outcrossing rates, have distinct sexes, and reproduce both sexually and asexually.

One area of research interest concerns the influence of mating behavior on levels of heterozygosity. Largely self-pollinated species tend to be much more homozygous than outcrossed ones, since heterozygote percentages are reduced by $50 \%$ with each generation of selfing. An outcrossed, heterozygous species is thought to have the greatest genic flexibility with which to respond to environmental change; the selfing, homozygous ones are considered to be betteradapted to unchanging conditions (Williams, 1975).

The North American strawberry species F. vesca and F. chiloensis display very different mating systems. F. vesca is hermaphroditic and primarily self-pollinated (Arulsekar and Bringhurst, 1981a), while F. chiloensis is mostly dioecious and outcrossed (Hancock and Bringhurst, 1980). California populations of these species have been examined for isozyme variability in three enzyme systems and their levels of heterozygosity do indeed appear to dif- fer. Heterozygous individuals of $F$. vesca are quite rare and have only been found in a few natural populations, while $F$. chiloensis is highly heterozygous at most sites (Hancock and Bringhurst, 1978, 1979a; Arulsekar and Bringhurst, 1981a). Part of the reason $F$. chiloensis is so heterozygous is due to its octoploid nature and the presence of multiple copies of most genes, but at least some of the variability has been shown to be intra-locus (Arulsekar and Bringhurst, 1981b). An interesting comparison would be between $F$. chiloensis and $F$. virginiana, since both are octoploid, but hermaphrodism is much more common in $F$. virginiana (M. Stahler and J. Luby, personal communication).

A considerable amount of ecological theory has also been devoted to the evolution of secondary sex characteristics in plants. The prevailing hypothesis is that the relative proportion of male (staminate) and female (pistillate) plants in nature depends on the "costs" of the two types of strategies; if females allocate more energy to fruit than males, they will also suffer higher rates of mortality because they put less energy into competitive structures (Godley, 1964; Lloyd, 1973; Lloyd and Wiebb, 1977). Darwin (1877) suggested that polleniferous forms of strawberries "increase rapidly and tend to supplant the females". Hancock and Bringhurst (1980) found support for this idea as female $F$. chiloensis allocated $8 \%$ more of their carbon into reproduction than males and there were $8 \%$ fewer females found in nature. Staudt (1967) found predominately pistillate biased sex ratios in seeds from open-pollinated $F$. chiloensis, but he did not measure survivorship.

Hancock and Bringhurst (1979b) also found that a high proportion of male $F$. chiloensis were polygamodioecious and produced a few early, hermaphrodite flowers. The males bloomed earlier than the females and the contribution of the primarily pistillate plants to the next generation may have been raised by the early flowers producing fruit without greatly affecting survivorship.

M. Stahler and J. Luby (personal communication) found pure males to be extremely rare in $F$. virginiana in Minnesota and there were almost twice as many hermaphrodites as females. However, the fruitfulness of hermaphrodites was highly variable, depending on environmental conditions. The hermaphrodites may have predominated in nature because they could reduce their reproductive effort under stressful conditions and survive, while the females produced copious fruit and died before completing reproduction. It is unknown whether $F$. chiloensis in California and $F$. virginiana in Minnesota have evolved separate sex strategies or if they are on different ends of a continuum.

The factors regulating allocation to sexual and asexual reproduction has also received considerable attention among ecologists. McArthur and Wilson (1967) suggested that, in areas with high density-independent mortality, types would be selected with high reproductive efforts, while in areas with primarily density-dependent mortality, types would be selected with increased competitive ability. In species capable of both sexual and asexual reproduction, sexual reproduction would be favored in cases of high densityindependent mortality and asexual reproduction would be beneficial in highly competitive environments (Ogden, 1974; Abrahamson, 1979).

Data have been collected on wild strawberries to test these theories, and the results have been conflicting, at best. Holler and Abrahamson (1977) found vegetative reproduction effort to be positively correlated with plot density, but they did not observe a significant relationship between density and degree of sexual reproduction. Jurik (1983) observed a weak relationship between both sexual and vegetative reproductive effort and degree of habitat disturbance. Hancock and Bringhurst (1978, 1979a) found reproductive patterns that were in direct opposition to predictions (Table 
Table 1. Wild strawberries of the world.

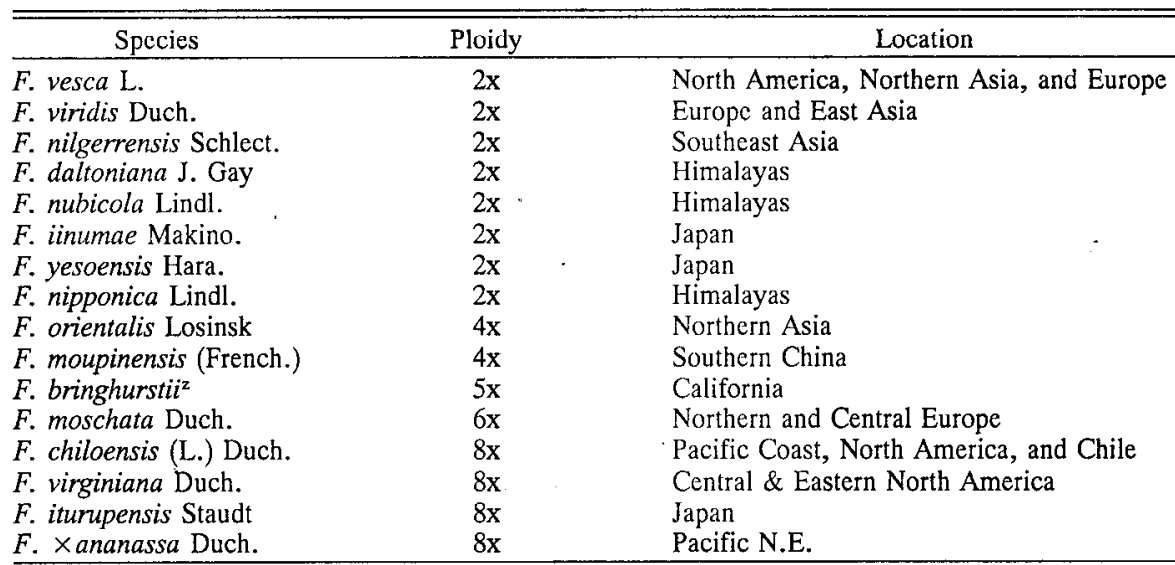

${ }^{2}$ Currently is an unnamed taxon worthy of species recognition. The populations are morphologically distinct, sexually isolated, and well-characterized (Bringhurst and Khan, 1963).

Table 2. Ecotypes of Fragaria vesca and $F$. chiloensis found in California (data from Hancock and Bringhurst, 1978, 1979a).

\begin{tabular}{|c|c|c|c|c|c|c|c|c|}
\hline \multirow[b]{3}{*}{ Species } & \multirow[b]{3}{*}{ Environment } & \multirow{3}{*}{$\begin{array}{c}\text { Mean } \\
\text { rainfall } \\
\left(\mathrm{mm} \cdot \text { year }^{-1}\right)\end{array}$} & \multirow{2}{*}{\multicolumn{2}{|c|}{$\begin{array}{l}\text { Mean temp. } \\
\left({ }^{\circ} \mathrm{C}\right)\end{array}$}} & \multicolumn{4}{|c|}{ Soil characteristics } \\
\hline & & & & & \multirow[b]{2}{*}{ Type } & \multicolumn{3}{|c|}{ Salinity } \\
\hline & & & January & July & & $\% \mathrm{C}$ & $\mathrm{ppm}$ & $\mathrm{pH}$ \\
\hline F. vesca & $\begin{array}{l}\text { Headland scrub } \\
\text { Coastal forest } \\
\text { Sierran forest }\end{array}$ & 686 & $\begin{array}{l}8.9 \\
6.5\end{array}$ & $\begin{array}{l}15.9 \\
16.7 \\
17.2\end{array}$ & & $\begin{array}{l}2.8 \\
5.9 \\
5.5\end{array}$ & $\begin{array}{l}497 \\
326 \\
205\end{array}$ & $\begin{array}{l}6.0 \\
6.3 \\
5.6\end{array}$ \\
\hline F. chiloensis & $\begin{array}{l}\text { Dunes } \\
\text { Coastal strant } \\
\text { Headland scrub } \\
\text { Woodland-meadows }\end{array}$ & $\begin{array}{r}476 \\
1837 \\
482 \\
1416\end{array}$ & $\begin{array}{r}10.4 \\
7.7 \\
9.5 \\
7.9\end{array}$ & $\begin{array}{r}10.5 \\
8.1 \\
10.3 \\
8.2\end{array}$ & $\begin{array}{l}\text { Sand } \\
\text { Sand } \\
\text { Silt loam } \\
\text { Sandy loam }\end{array}$ & $\begin{array}{l}0.3 \\
0.3 \\
2.8 \\
2.8\end{array}$ & $\begin{array}{l}663 \\
652 \\
497 \\
390\end{array}$ & $\begin{array}{l}6.7 \\
6.7 \\
6.0 \\
5.4\end{array}$ \\
\hline
\end{tabular}

Table 3. Number of runners and flowers produced by strawberries from variant environments. Raw data from Hancock (1977) and Hancock and Bringhurst (1978, 1979a).

\begin{tabular}{|c|c|c|c|c|c|}
\hline Species & Environment & $\begin{array}{c}\text { No. } \\
\text { runners }\end{array}$ & $\begin{array}{c}\text { No. } \\
\text { flowers }\end{array}$ & $\mathrm{SRE}^{2}$ & $\begin{array}{c}\text { Plants } \\
\text { flowering (\%) }\end{array}$ \\
\hline F. vesca & $\begin{array}{c}\text { Scrub } \\
\text { Forest } \\
\text { SE }\end{array}$ & $\begin{array}{l}83.2 \\
43.4 \\
31.2\end{array}$ & $\begin{array}{r}8.2 \\
26.6 \\
7.5\end{array}$ & $\begin{array}{l}-- \\
---\end{array}$ & $\begin{array}{l}57 \\
93\end{array}$ \\
\hline$F$. chiloensis & $\begin{array}{l}\text { Scrub } \\
\text { Dunes } \\
\text { Strand } \\
\text { Woodland- } \\
\quad \text { meadow } \\
\text { SE }\end{array}$ & $\begin{array}{l}51.7 \\
32.0 \\
38.2 \\
51.9 \\
\\
\\
14.5\end{array}$ & $\begin{array}{l}10.6 \\
15.9 \\
29.1 \\
37.2 \\
\\
3.9\end{array}$ & $\begin{array}{l}0.53 \\
0.60 \\
0.62 \\
0.73\end{array}$ & $\begin{array}{l}65 \\
53 \\
97 \\
95\end{array}$ \\
\hline
\end{tabular}

${ }^{2}$ SRE $($ sexual reproductive effort $)=$ biomass in fruit/biomass in vegetative structures $\times 100$.

3). Flower numbers were most prevalent in the dense forest sites of $F$. vesca and the disturbed woodland-meadow sites of $F$. chiloensis. Runner numbers were highest in the low-density scrub sites of $F$. vesca and in both the woodland-meadow and scrub sites of $F$. chiloensis. Clearly, unidentified abiotic factors are overriding the effects of density on patterns of resource allocation in strawberries or the relationship between sexual and asexual reproduction is effectively neutral. More-precise measurements of survival must be made to adequately test these possibilities, since runners are photosynthetically active and their survivorship may be largely independent of the mother plant.

Fragaria is a broadly adapted genus and substantial differentiation has occurred both within and between the species in response to a wide range of environmental conditions. Substantial variation has been observed in temperature, salt, moisture, and shade tolerances. Sexual selection has played an important role in the ecological differentiation of strawberries, along with numerous other morphological and physiological adaptations.

\section{Literature Cited}

Abrahamson, W.G. 1979. Patterns of resource allocation in wildflower populations of fields and woods. Amer. J. Bot. 66:71-80.

Angevine, M.W. 1983. Variations in the demography of natural populations of the wild strawberries Fragaria vesca and $F$. virginiana. J. Ecol. 71:959974.

Arulsekar, S. and R.S. Bringhurst. 1981a. Genetic model for the enzyme marker PGI, its variability and use in elucidating the mating system in diploid California Fragaria vesca L. J. Hered. 72:117-120.

Arulsekar, S., R.S. Bringhurst, and V. Voth. 1981b. Inheritance of PGI and LAP isozymes in octoploid cultivated strawberries. J. Amer. Soc. Hort. Sci. 106:679-683.

Bringhurst, R.S. and D.A. Khan. 1963. Natural pentaploid Fragaria chiloensis - F. vesca hybrids in coastal California and their significance in polyploid Fragaria evolution. Amer. J. Bot. 50:658-661.

Cameron, J.S. and C.A. Hartley. 1988. Gas exchange and photosynthate partitioning characteristics of Fragaria chiloensis germplasm. HortScience 23:821. (Abstr.)

Chabot, B.F. 1978. Environmental influences on photosynthesis and growth 
in Fragaria vesca. New Phytol. 80:87-98.

Darrow, G.M. 1966. The strawberry. History, breeding and physiology. Holt, Rinehart and Winston, New York.

Darwin, C. 1877. The different forms of flowers on plants of the same species. Murray, London.

Godley, E.J. 1964. Breeding systems in New Zealand plants: III. Sex ratios in some natural populations. New Zealand J. Bot. 2:205-212.

Goncharova, E.A., L.G. Dobrenkova, and E.V. Mazhorov. 1978. Comparative drought resistance of strawberries from different ecological and geographical zones. Byull. Vsesoyuznogo Ordena Lenian Ordena Druzhby Narodov Inst. Rasten. Imeni N. I. Vavilova No. 86:18-21. [Plant Breed. Abstr. 50:9599].

Goncharova, E.A. and L.D. Dobrenkova. 1981. Growth processes and yield in strawberry under conditions of drought and salinity. Trudy Priklandoi Bot. Gen: Selektsii 70:97-102. [Plant Breed. Abstr. 54:9189].

Hancock, J.F. 1977. Ecogenetics of California species of Fragaria: Habitats, morphology, enzymes, and physiological tolerances of octoploid $F$. chiloensis and $F$. virginiana. and diploid $F$. vesca. PhD Diss., Univ. of C a 1 i f o r n i a, D a vi s.

Hancock, J.F. and R.S. Bringhurst. 1978. Interpopulational differention and adaptation in the perennial, diploid species Fragaria vesca L. Amer. J. Bot. 65:795-803.

Hancock, J.F. and R.S. Bringhurst. 1979a. Ecological differentiation in perennial, octoploid species of Fragaria. Amer. J. Bot. 66:367-375.

Hancock, J.F. and R.S. Bringhurst. 1979b. Hemaphrodism in predominately dioecious populations of Fragaria chiloensis (L.). Duchn. Bul. Torrey Bot. Club 106:229-231.

Hancock, J.F. and R.S. Bringhurst, 1980. Sexual dimorphism in the strawberry Fragaria chiloensis. Evolution 34:762-768.
Hancock, J.F., J.A. Flore, and G.J. Galletta. 1989. Gas exchange properties of strawberry species and their hybrids. Scientia Hort. (In press.)

Holler. L.C. and W.G. Abrahamson. 1977. Seed and vegetative reproduction in relation to density in Fragaria virginiana (Rosaceae). Amer. J. Bot. 64:1003-1007.

Jensen, R.J. and J.F. Hancock. 1982. Multivariate relationships among California strawberries. Bul. Torrey Bot. Club 109:136-147.

Jurik, T.W. 1983. Reproductive effort and $\mathrm{CO}_{2}$ dynamics of wild strawberry populations. Ecology 64:1329-1342.

Jurik, T.W., J.F. Chabot, and B.F. Chabot. 1979. Ontogeny of photosynthetic performance in Fragaria virginiana under changing light regimes. Plant Physiol. 63:542-547.

Lloyd, D.G. 1973. Sex ratios in sexually dimorphic Umbelliferae. Heredity 31:239-249.

Lloyd, D.G. and C.J. Webb. 1977. Secondary sex characteristics in plants. Bot. Rev. 43:177-216.

MacArthur, R.H. and E.O. Wilson. 1967. The theory of island biography. Princeton Univ. Press, Princeton, N.J.

Ogden, J. 1974. The reproductive strategy of higher plants: II. The reproductive strategy of Tussilago farfara. J. Ecol. 62:291-324.

Stadler, M.M.; J.J. Luby, P.D. Ascher, and G.J. Galletta. 1988. Evaluation of genetic diversity in wild populations of Fragaria virginiana. HortScience 23:738. (Abstr.)

Staudt, G. 1962. Taxonomic studies in the genus Fragaria. Can. J. Bot. 40:869-886

Staudt, G. 1967. Die Genetik und Evolution der Heterozie in der Gattung III. Untersuchungen an hexa- und oktoploiden Arten. Z. Planzezuchtg. 59:83-102.

Williams, G.C. 1975. Sex and evolution. Princeton Univ. Press, Princeton, N.J. 